Chirurgia (2019) 114: 121-125

No. 1, January - February

Copyright@ Celsius

http://dx.doi.org/10.21614/chirurgia.114.1.121

\title{
Retrohepatic Gallbladder Masquerading as Hydatid Cyst in a Patient with Right Liver Agenesis
}

\author{
Georgian Diaconu', Alexandru Martiniuc ${ }^{1,2}$, Ioana Lupescu ${ }^{1,3}$, Mihai Ceausu ${ }^{1,4}$, Traian Dumitrascu ${ }^{1,2}$ \\ ${ }^{1}$ Carol Davila University of Medicine and Pharmacy, Bucharest, Romania \\ ${ }^{2}$ Center of General Surgery and Liver Transplant, Fundeni Clinical Institute, Bucharest, Romania \\ ${ }^{3}$ Department of Radiology, Medical Imaging and Interventional Radiology, Fundeni Clinical Institute, Bucharest, Romania \\ ${ }^{4}$ Department of Pathology, Mina Minovici National Institute of Legal Medicine, Bucharest, Romania
}

Corresponding author:

Traian Dumitrascu, MD

Carol Davila University of Medicine

and Pharmacy, Center of General

Surgery and Liver Transplant

Fundeni Clinical Institute

Fundeni Street no 258, 022328,

Bucharest, Romania

E-mail: traian.dumitrascu@umfcd.ro

\section{Rezumat}

Veziculă biliară retrohepatică sugerând un chist hidatic la un pacient cu agenezie de lob drept hepatic

Agenezia de lob drept hepatic este o anomalie congenitală rară, ce poate fi asociată cu veziculă biliară ectopică. Este prezentat cazul unui pacient de 39 de ani investigat pentru dureri în hipocondrul drept şi diagnosticat le examinarea computer tomograf cu o masă chistică la nivelul ficatului, interpretată inițial ca fiind un chist hidatic. După laparotomie, diagnosticul a fost de agenezie de lob drept hepatic, iar presupusul chist hidatic era in fapt o veziculă biliară cu dispoziție retrohepatică, cu conținut litiazic. S-a practicat colecistectomie, cu evoluție postoperatorie favorabilă. Reevaluarea imaginilor examinării computer tomograf de către un radiolog experimentat a confirmat diagnosticul intraoperator. Deşi agenezia de lob drept hepatic cu veziculă biliară retrohepatică constituie o entitate clinică de excepție, chirurgii trebuie să fie avizați asupra existeței acestei anomalii deoarece poate pune probleme atât de diagnostic cât şi de strategie chirurgicală, în timpul colecistectomiei.

Cuvinte cheie: veziculă biliară retrohepatică, agenezie de lob drept hepatic, computer tomografie

\section{Abstract}

Agenesis of the right liver is a rare congenital anomaly which can www.revistachirurgia.ro 
be associated with an ectopic gallbladder. Hereby, it is presented the case of a 39-year-old man investigated for right upper quadrant abdominal pain and diagnosed at computed tomography with a cystic liver mass initially considered as hydatid cyst. At laparotomy, it was discovered agenesis of the right liver and the presumed hydatid cyst was a retrohepatic gallbladder with lithiasis. Cholecystectomy was performed with an uneventful outcome. Reassessment of the computed tomography images by an experienced radiologist confirmed the intraoperative diagnosis. Although agenesis of the right liver with retrohepatic gallbladder is an exceptional appearance, surgeons should be aware of this anomaly because it can raise challenging issues of diagnosis and surgical planning during cholecystectomy.

Key words: retrohepatic gallbladder, right liver agenesis, computed tomography

\section{Introduction}

Retrohepatic gallbladders have been reported in the literature in few patients and are usually associated with other abnormalities such right liver agenesis or hypoplasia $(1,2)$. However, the diagnosis of this uncommon pathology is sometimes challenging. Hereby it is presented the case of a patient with a retrohepatic gallbladder that was preoperatively misinterpreted as a hydatid cyst of the liver.

\section{Case report}

A 39-year-old man was admitted to Fundeni Clinical Institute in Bucharest for right upper quadrant abdominal pain. The symptoms appeared few months before the presentation. The medical history included a laparotomy for unknown reasons. The clinical examination did not reveal any pathological changes. The laboratory findings were within normal limits, except for a mild elevation of serum aminotransferase levels. Contrast-enhanced computed tomography revealed a large cystic liver lesion of 9.6/5.5/ $4.9 \mathrm{~cm}$, with a $2 / 1.5 \mathrm{~cm}$ nodular calcification; the cystic lesion was well circumscribed, with iodophyl thickened walls of $0.3 \mathrm{~cm}$ and fluid content (Fig. 1). The lesion was initially considered a hydatid cyst. It was also noticed the absence of right liver (parenchyma, right hepatic vein, right portal vein, right hepatic artery) (Fig. 2-3). Furthermore, the ELISA test for Echinococcus granulosus was equivocal. With a preoperative diagnosis of hydatid cyst of the liver, the patient was submitted to surgery in May, 2017. At laparotomy, the presumed hydatid

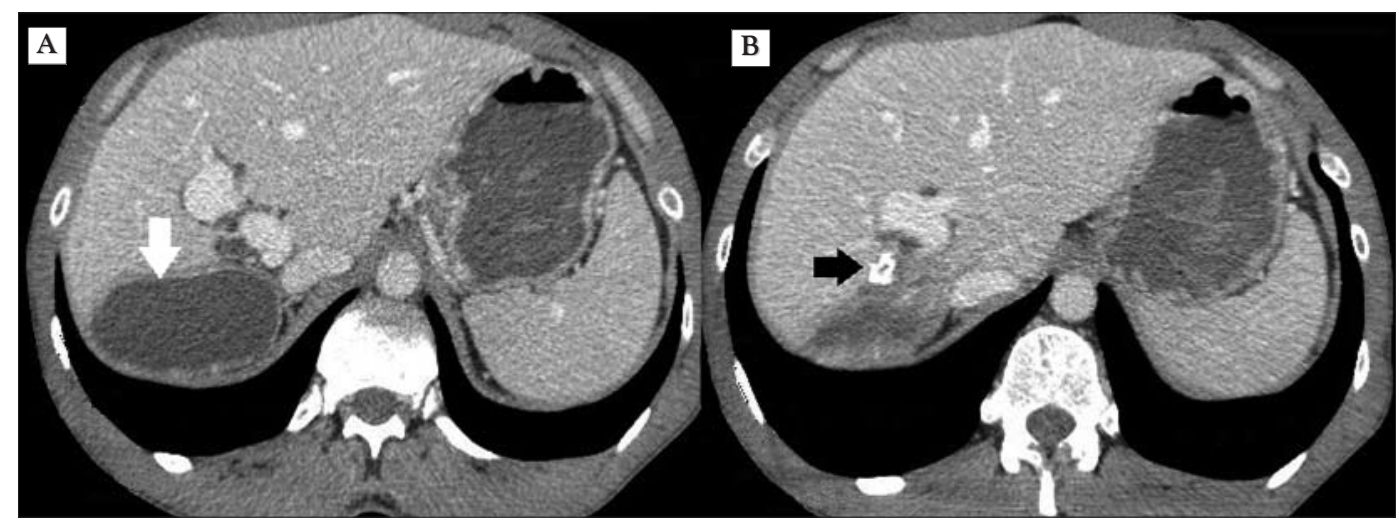

Figure 1. Contrast-enhanced computed tomography (axial plane) showing (A) the cystic lesion of the liver (white arrow) with (B) calcifications (black arrow) suggesting a liver hydatid cyst. 


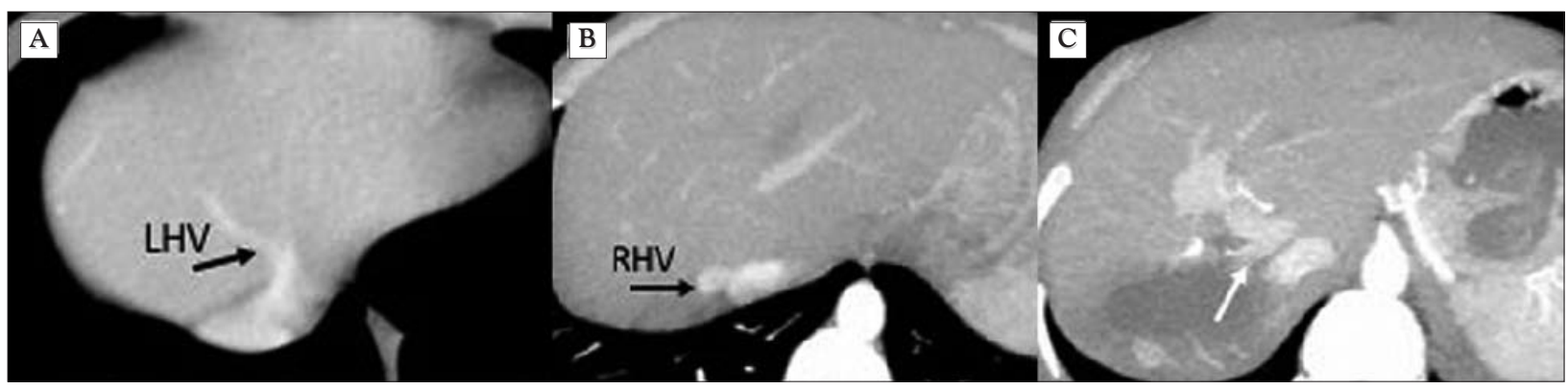

Figure 2. Contrast-enhanced computed tomography (axial plane) showing (A) dominant pattern of the left hepatic vein (LHV), (B) absence of the right hepatic vein (RHV) and (C) absence of the right portal vein (arrow)

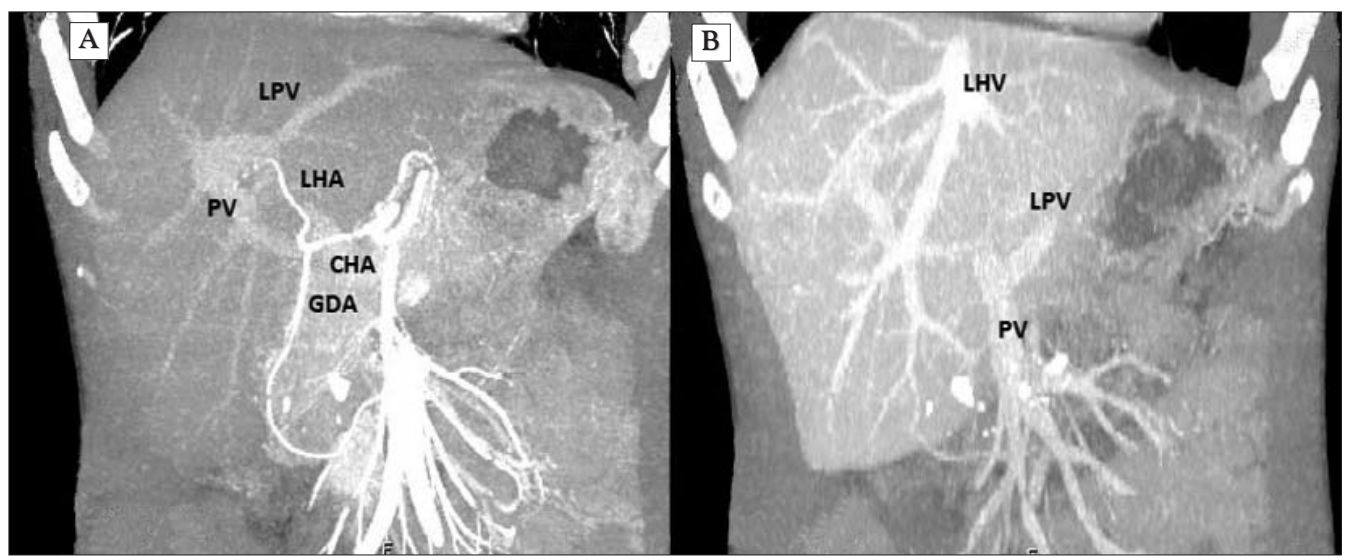

Figure 3. Contrast-enhanced computed tomography (frontal plane) showing (A) presence of only left portal vein (LPV) and left hepatic artery (LHA) and absence of right portal vein and right hepatic artery and (B) dominant pattern of left hepatic vein (LHV) and absence of right and middle hepatic veins (PV - main portal vein; CHA - common hepatic artery; GDA - gastro-duodenal artery).

cyst of the liver was actually a retrohepatic gallbladder with lithiasis associated with agenesis of the right liver and compensatory hypertrophy of the left liver (Fig. 4). A cholecystectomy was performed with an uneventful postoperative outcome; the patient was discharged on postoperative day 5 .

Reassessment of the computed tomography images by an experienced radiologist confirmed the intraoperative diagnosis. Thus, it was

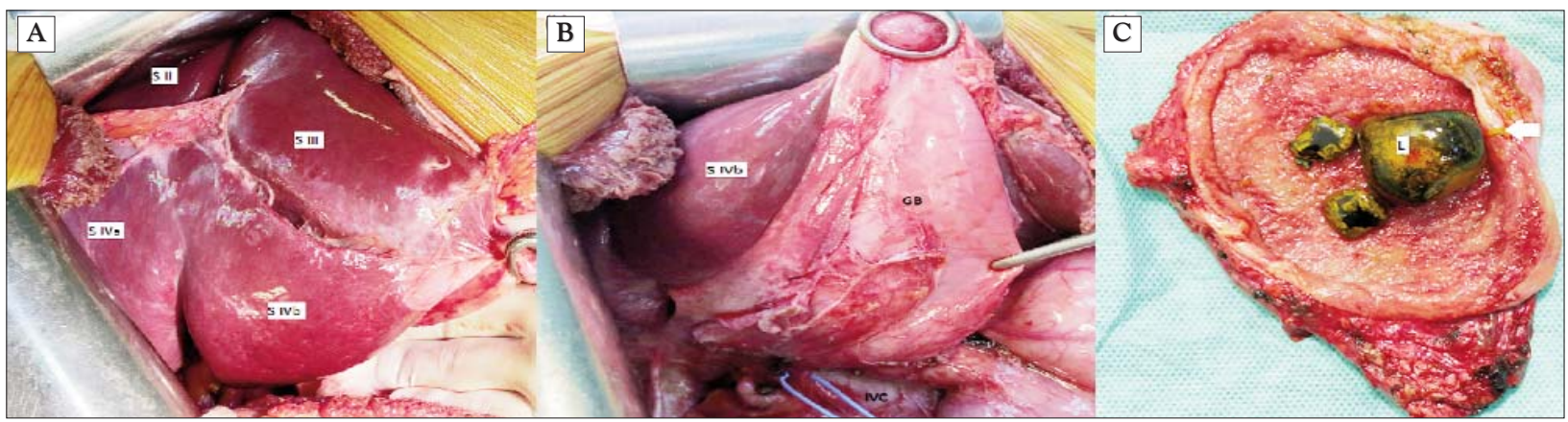

Figure 4. Intraoperative aspects showing (A) agenesis of the right liver with the presence of only segments II-IV of the liver, (B) retrohepatic gallbladder (GB), close to the inferior vena cava (IVC) and (C) operative specimen of the gallbladder with thickened walls (arrow) and lithiasis (L). 


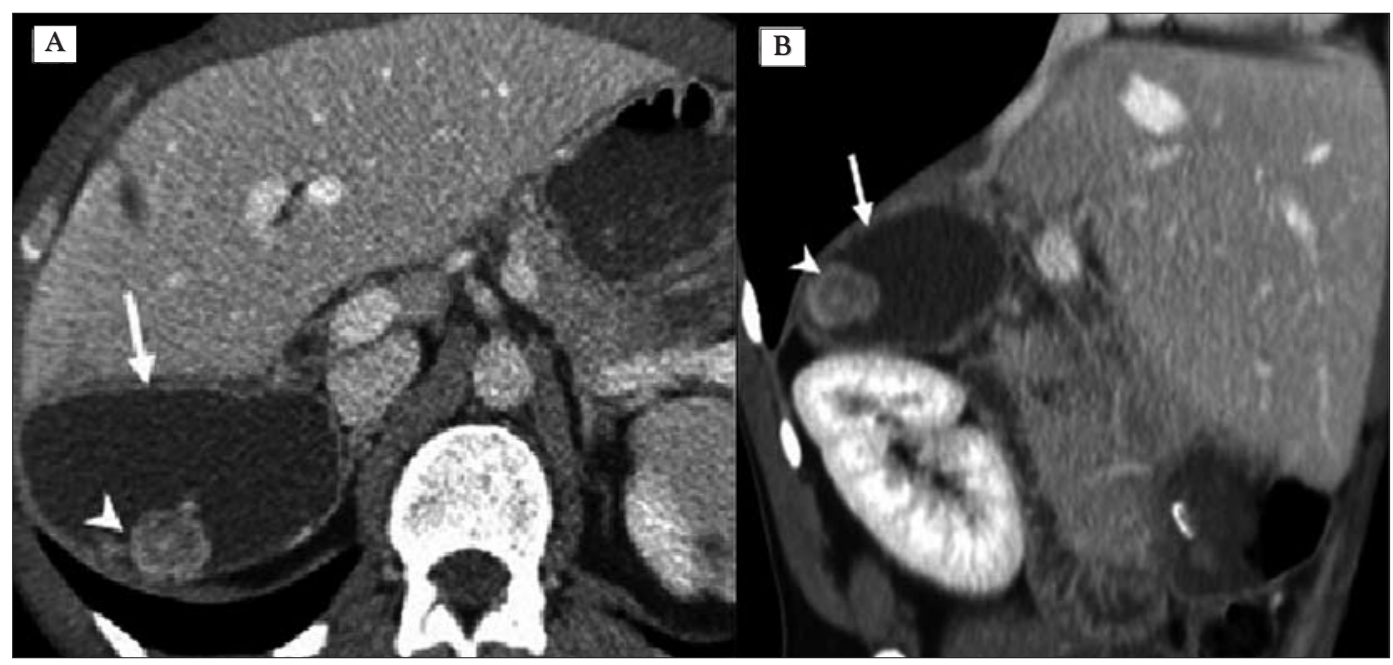

Figure 5. Contrast-enhanced computed tomography. $\mathbf{A}$ - axial plane and $\mathbf{B}$ - oblique sagittal plane) showing a retrohepatic gallbladder (arrow) with thickened walls and lithiasis (arrowhead).

observed the retrohepatic gallbladder with lithiasis, agenesis of right liver, with the absence of right portal vein, right hepatic vein and right hepatic artery, and the compensatory hypertrophy of the left liver (Fig. 5- 6).

\section{Discussion}

Agenesis of the right liver is a rare congenital anomaly, with slightly male predominance, defined by the absence of liver tissue on the right side, without previous disease or surgery (1-4). The absence of right hepatic vein, right portal vein and the right hepatic artery is highly suggestive for diagnosis of right liver agenesis (1). It is assumed that this anomaly is caused by the developmental failure of the right portal vein or an error in mutual induction between the primitive diaphragm and the endodermal diverticulum representing the primitive liver (2). The condition is mostly asymptomatic and discovered accidentally, by

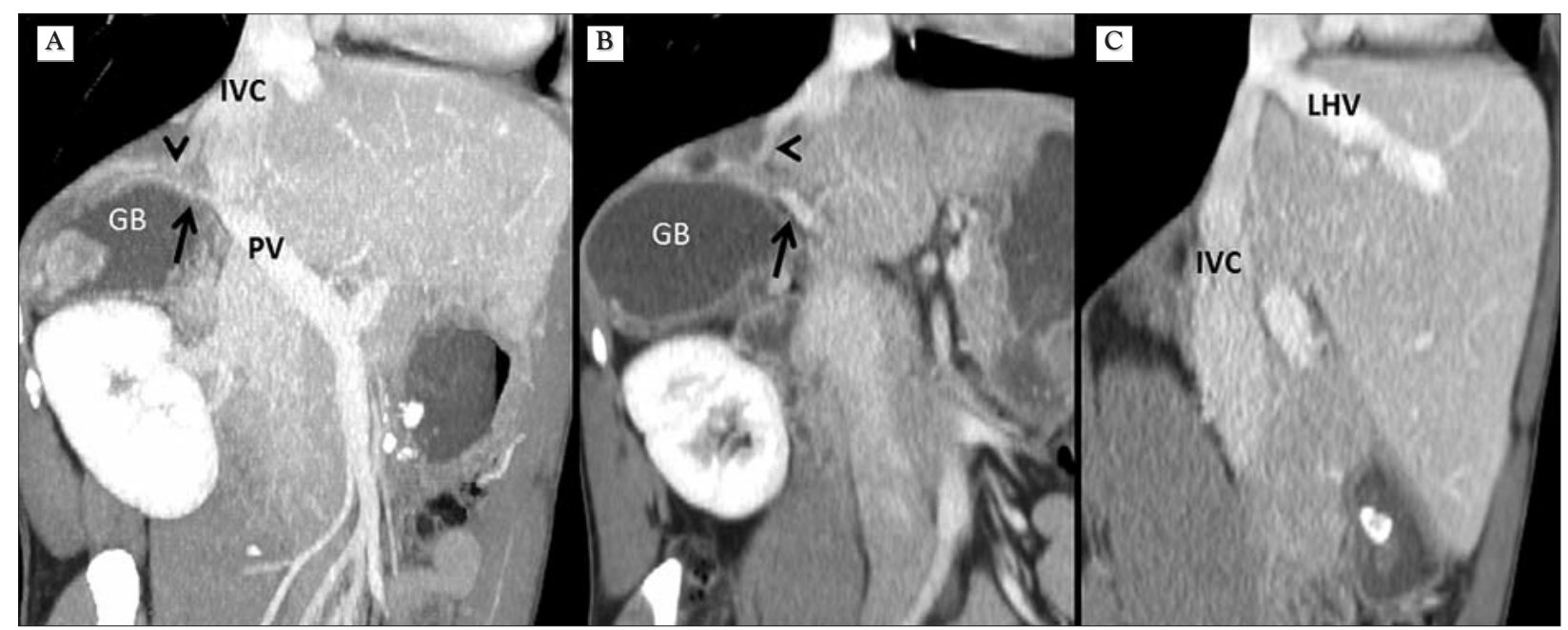

Figure 6. Contrast-enhanced computed tomography (parasagittal planes) showing (A, B) the absence of right hepatic vein (arrowhead) and right portal vein (arrow); and (C) dominant pattern of the left hepatic vein (LHV) and the absence of middle hepatic vein (GB - gallbladder; PV - main portal vein; IVC - inferior vena cava). 
imaging exams or abdominal surgery (1-4). The agenesis of the right liver is often associated with other anatomical variations or diseases such compensatory hypertrophy of the remaining segments, right diaphragmatic hernia, portal hypertension, the interposition of the hepatic flexure of the colon or ectopic gallbladder with or without lithiasis (1-4). It was presumed that a displaced gallbladder might favor the occurrence of lithiasis due to torsion or compression of cystic duct (2). An ectopic gallbladder might also increase the risk of bile duct injuries during cholecystectomy for lithiasis $(3,5)$. Thus, accurate preoperative localization of the gallbladder is of utmost importance to plan the surgical approach for cholecystectomy and to avoid complications. It is important to differentiate right liver agenesis from severe right lobe atrophy, which appears in other liver conditions such liver cirrhosis, cholangiocarcinoma or previous liver surgery $(1,2,4)$.

\section{Conclusions}

Although agenesis of the right liver with retrohepatic gallbladder is an exceptional appearance, surgeons should be aware of this anomaly because it can raise challenging issues of diagnosis and surgical planning during cholecystectomy.

\section{Conflicts of Interest}

The authors certify that there is no conflict of interest with any financial organization regarding the material discussed in the manuscript

\section{Funding: none}

\section{Authors' contributions}

GD, AM, IL, MC and TD all have made substantial contribution to acquisition of data, conception, analysis and interpretation of data. All authors have been involved in drafting the manuscript and revising it critically for important intellectual content. All authors read and approved the final manuscript and take public responsibility for appropriate portions of the content and agreed to be accountable for all aspects of work.

\section{References}

1. Chou CK, Mak CW, Lin MB, Tzeng WS, Chang JM. CT of agenesis and atrophy of the right hepatic lobe. Abdom Imaging 1998; 23(6):603-7.

2. Radin DR, Colletti PM, Ralls PW, Boswell WD, Jr., Halls JM. Agenesis of the right lobe of the liver. Radiology 1987;164(3):639-42.

3 . Fields RC, Heiken JP, Strasberg SM. Biliary injury after laparoscopic cholecystectomy in a patient with right liver agenesis: case report and review of the literature. J Gastrointest Surg 2008;12(9):1577-81.

4. Inoue T, Ito Y, Matsuzaki Y, Okauchi Y, Kondo H, Horiuchi N, et al. Hypogenesis of right hepatic lobe accompanied by portal hypertension: case report and review of 31 Japanese cases. J Gastroenterol 1997;32(6):836-42.

5. Paik KY. Biliary injury after cholecystectomy in a patient with severe right liver atrophy. J Korean Surg Soc 2013;84(3):185-8. 